\title{
Hispanofilia en los Estados Unidos
}

Thomas Jefferson, célebre Presidente de los Estados Unidos, aconsejó a su sobrino en 1787: "Lengua española. Préstale mucha atención, y procura conocerla en detalle. Por nuestras relaciones venideras con España y la América Hispánica esa lengua llegará a ser una adquisición de mucho provecho. La historia antigua de gran parte de América también se ha escrito en aquel idioma; te envío un diccionario."

Benjamin Franklin solía citar proverbios castellanos; y Henry David Thoreau soñó con la idea de hacerse cartero en el Perú. Creyendo inicua la posición yanqui en la guerra con México, este famoso ensayista se negó a pagar ciertos impuestos federales, y por tal contumacia pasó la noche en la cárcel de Concord. El héroe de una de las primeras novelas norteamericanas, Francis Berrian (1826), declaró a sus amigos mexicanos que en los Estados Unidos la gente baja desdeñaba a España, pero "toda la clase alta apreciaba el carácter español."

Un siglo después de la eđad Jeffersoniana, profetizó el más conocido poeta estadounidense, Walt Whitman:

A nosotros los norteamericanos todavía nos queda el trabajo de conocer a nuestros antepasados, y clasificarlos, unirlos. Resultarán más diversificados de lo que se ha supuesto, y de orígenes muy. distintos. Hasta ahora, adoctrinados por escritores y maestros de escuela de Nueva Inglaterra, tácitamente pensamos que se han creado nuestros Estados Unidos sólo de las Islas Británicas, y que esencialmente no constituimos más que una Inglaterra secundaria... lo cual es equivocación enorme. Veremos que muchos de los rasgos de nuestra personalidad futura, algunos de ellos sobresalientes, han provenido de un linaje no inglés. ... A esa compuesta identidad americana del porvenir, el carácter español abaste- 
cerá umo de los elementos más vitales. Ninguna estirpe revela una historia retrospectiva más impresionante... más impresionante desde el punto de vista de lo religioso y de lo leal, o en cuanto al patriotismo, a la valentía, al decoro, a la majestad y al honor... Ya es hora de que nos demos cuenta... de que en el resumen de la antigua historia española no se hallarán más crueldad, tiranía, superstición, etcétera, que en el resumen correspondiente de la historia anglo-normanda. Al contrario, creo que no se encontrará tanto.

Estos ejemplos, y otros muchos que podríamos dar, indican, de parte de distinguidos literatos norteamericanos de los siglos XVIII y xIx, un vivo interés por las cosas españolas. Es curioso, sin embargo, que no se haya estudiado esto suficientemente. Hay ya una copiosa bibliografía sobre otras influencias extranjeras reflejadas en la literatura estadounidense; pero, según observa cierta autoridad en la materia, "todavía no se ha hecho ningún examen de la contribución española a la Anérica del norte." Atraídos por el prestigio de otras culturas europeas los estudiosos norteamericanos no han visto bien el constante interés que en nuestro país se ha sentido por el mundo hispánico.

En una tesis doctoral, todavía inédita, he explorado el vasto territorio de novelistas, dramaturgos y poetas que, antes de 1831, usaron temas españoles. ${ }^{1} \mathrm{El}$ objeto del presente artículo se reduce a señalar tan sólo las corrientes más visibles de la atención norteamericana a lo hispánico.

Un estudio completo comprendería cuatro períodos. En el primero, hasta 1830 , se arrojaron las semillas de la boga española. Aun los líderes culturales más renombrados eran profesores y estudiantes de castellano: Henry Wadsworth Longfellow, George Ticknor y varios otros. Viajes a España llegaron a ser la moda romántica del día para miembros de la sociedad alta o erudita, como Ticknor, quien afirmó: "España y los españoles me cautivan más que cualquier otra cosa que he visto en Europa." Famosos estadistas como John Adams y James Monroe visitaron la Península; norteamericanos eminentes como David Humphreys, James Bowdoin y Alexander Everett sirvieron en el cuerpo diplomático de Madrid.

Esta actividad hispanizante en círculos académicos y diplomáticos se reflejaba en la literatura. Abundaban novelas cuya acción 
tenía lugar en España o en el Caribe, y que trataban de héroes como Colón o de legendarios piratas. Novelistas "góticos" como Charles Brockden Brown enviaron sus protagonistas malvados a que aprendieran nigromancia en la España inquisitorial, la España que fascinaba a Edgar Allan Poe. Modern Chivalry, de Hugh Henry Brackenridge, captó no sólo la estructura complicada del Quijote, sino también algo del espíritu. William Dunlap, "padre del escenario yanqui", produjo un sinfín de piezas basadas en temas españoles o hispano-americanos; otros dramaturgos trajeron de París unas traducciones de la comedia del Siglo de Oro. Respecto a la poesía, Philip Freneau y Joel Barlow encontraron en Colón un símbolo de la libertad mundial; y William Cullen Bryant empezó a publicar sus exquisitas traducciones de versos españoles renacentistas.

La semilla dió fruto durante el segundo período, en la época romántica que se extendió desde 1831 hasta 1865 , fecha de la guerra civil en los Estados Unidos. Gentes muy cultas, como Washington Irving, seguían la costumbre de viajar por la Península y algunos sirvieron en la embajada norteamericana de Madrid. La boga por escenas españolas llegó al colmo en obras de los más célebres entre los primeros novelistas yanquis: James Fenimore Cooper, Herman Melville y William Gilmore Simms. Josep̉h Holt Ingraham y Robert Montgomery Bird hicieron uso de escenas mexicanas; y el último de los mencionados ofreció, junto con George Henry Boker, pesados dramas románticos que se basaban en temas hispánicos. Longfellow continúa el ejemplo de Bryant con hermosas traducciones, pero la contribución prominente se hallaba en el terreno de la historia artística, es decir, en las grandes narraciones de España e Hispano-América por Irving y William Hickling Prescott.

Durante la tercera época - hasta la guerra de 1898- literatos estadistas como James Russell Lowell y John Hay se dirigieron a España. Hubo una invasión de distinguidos viajeros femeninos, como Harriet Trowbridge Allen y Mrs. James Claghorn. Otra hornada de historiadores continuó la tradición de Washington Irving. $Y$ otra vez el conocimiento de mundos hispánicos se reflejó en la literatura: en la prosa de Bret Harte y Edward Everett Hale, por ejemplo, y en la poesia de Joaquín Miller y Walt Whitman.

Así como los románticos se habían escapado a España y a la América Hispánica en busca de lo exótico, ahora, en la época con- 
temporánea, han de encontrar temas alli los realistas. E1 mundo español provee el tema de la tauromaquia, explotado en la literatura por Ernest Hemingway, Tom Lea y Barnaby Conrad. En territorios estadounidenses de habla española, los realistas John Steinbeck, John dos Passos y Willa Cather han hallado lo sórdido o lo patético. El gran poeta Archibald MacLeish ganó el premio Pulitzer por su interprétación del tema de la "Noche Triste." Varios autores españoles -Blasco Ibáñez, Unamuno, García Lorca, etcétera- han gozado de una boga especial entre ciertos círculos recónditos de Nueva York. Harriet de Onís y Katherine Anne Porter han continuado en el campo de la traducción, esta última publicando en inglés una bella edición de El Periquillo Sarniento; entretanto, en el plano académico Irving Leonard $\mathrm{y}$ otros siguen acabando con la "leyenda negra".

Las razones de estas corrientes hispanófilas son muchas y demasiado complicadas para este breve artículo. Ante todo, resultaron de sucesos políticos que antaño ligaron los Estados Unidos a España. Segundo, bajo la inspiración de Irving los escritores del siglo XIX buscaron una literatura "nacional", y en esta busca no se podía pasar por alto el papel de España en el descubrimiento y establecimiento del Nuevo Mundo. Tercero, por el impulso romántico a principios del siglo pasado, Norteamérica se volvió hacia la Península, el país que, para los yanquis, dice cierto historiador "ha tenido a veces más encanto romántico que todo el resto de Europa." (Este encanto resultó quizá de que físicamente España había cambiado relativamente poco desde la Edad Media y seguía preservando bellos vestigios moriscos.) Por último, muchos fueron los escritores inspirados por libros castellanos, y muchas fueron las obras accesibles, como señala Harry Bernstein en un artículo sobre la increíble cantidad de crónicas e historias españolas en las primeras bibliotecas de Norteamérica.

Frederick S. Stimison.

\section{NOTAS}

1 Stanley T. Williams, profesor en la Universidad de Yale, va a limitarse al período moderno en su nueva obra." Otro de los pocos investigadores de este tema, Miguel Romera-Navarro, en El hispanismo en Norteamérica (1917), al tratar de incluir todas lás épocas y todos los géneros omite mucho de' lo măs significativo. 